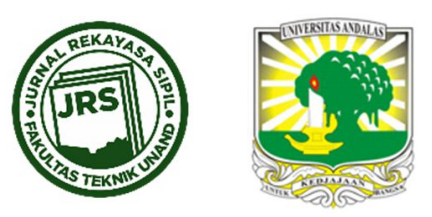

\title{
KESIAPAN PENYEDIA JASA KONSTRUKSI DALAM PELAKSANAAN K3 SELAMA PANDEMI COVID-19 DI PROVINSI SUMATERA BARAT
}

\author{
FEBIANA MAULANI $^{1}$, BENNY HIDAYAT ${ }^{2}{ }^{*}$, TAUFIKA OPHIYANDRI ${ }^{2}$ \\ ${ }^{1}$ Magister Teknik Sipil, Jurusan Teknik Sipil, Universitas Andalas, Padang, Sumatera Barat, Indonesia \\ ${ }^{2}$ Jurusan Teknik Sipil, Fakultas Teknik, Universitas Andalas, Padang, Sumatera Barat, Indonesia \\ *Corresponding author: $ه$ bennyhidayat@eng.unand.ac.id
}

Naskah diterima : 21 Oktober 2021. Disetujui: 20 Desember 2021

\begin{abstract}
ABSTRAK
Wabah Corona ditetapkan sebagai pandemi global sehingga Indonesia juga menetapkan standar protokol termasuk pada bidang konstruksi dengan mengeluarkan INMEN Menteri PUPR No 2 tahun 2020 tentang Pelaksanaan Protokol Pencegahan Covid - 19 pada Proyek Konstruksi sebagai pedoman yang harus dilaksanakan oleh penyedia jasa dalam masa pelaksanaan konstruksi di lingkungan proyek. Maka, Kesiapan dari penyedia jasa dalam penerapkan pelaksanan K3 protokol Covid - 19 perlu diulas lebih jauh baik dari sisi kemampuan SDM untuk mengimplementasikan pelaksanan protokol tersebut, ataupun dari segi manajerial perusahan sendiri dalam menyediakan peralatan SOP Covid - 19 di lingkungan proyek. Metode penelitian yang digunakan adalah wawancara kepada penyedia jasa, dan observasi ke lingkungan proyek. Hasil penelitian ini menunjukkan kesiapan SDM dan personil K3 dilapangan dalam pelaksanaan protokol covid - 19 adalah $66.66 \%$ atau penilaian baik, sedangkan untuk kesiapan dalam peralatan SOP protokol covid - 19 dilapangan hanya $60 \%$ atau penilaian cukup, dan penilaian kesiapan pelaksanaan protokol Covid - 19 keseluruhan adalah $63.42 \%$. Sehingga, hasil penelitian ini dapat menjadi dasar evaluasi dalam penerapan INMEN didalam proyek konstuksi kedepannya.
\end{abstract}

Kata kunci : Covid - 19, Protokol Covid - 19 Pada Proyek konstruksi, INMEN No 2 Tahun 2020

\section{PENDAHULUAN}

World Health Organization (WHO) pada 11 maret 2020 menetapkan wabah corona virus atau Covid-19 sebagai pandemi globa. Wabah ini awalnya ditemukan di Wuhan (Cina) dan kemudian menyebar ke negara lain. Sejauh ini, virus corona sudah menginfeksi lebih dari 118.000 orang di 114 negara. Penetapan status pandemi ini disebabkan oleh penyebaran yang begitu cepat dan luas hingga ke wilayah yang jauh dari pusat wabah. Dengan status pandemi ini WHO meminta seluruh Negara meningkatkan respon terhadap darurat Covid19 (Elvina, 2020). 
Merujuk pada penetapan wabah corona sebagai pandemi global maka WHO pun menetapkan standar protokol penanganan corona. Dengan penetapan pandemi tersebut, WHO meminta setiap negara untuk dapat mengaktifkan dan meningkatkan mekanisme tanggap darurat; mengomunikasikan kepada warga tentang risiko virus corona dan mengimbau mereka untuk melindungi dirinya sendiri; menemukan, mengisolasi, menguji dan merawat pasien Covid-19 dan melacak setiap kontak yang berkaitan dengan mereka (Widyaningrum, 2020).

Selaras dengan hal tersebut, Indonesia pun juga turut menerapkan dan menetapkan standar protokol dalam menangani kasus virus corona di Indonensia. Berdasarkan info dari kantor staf kepresidenan menyatakan protokol corona akan merujuk ke standar WHO. Sekjen Kementerian Kesehatan mengatakan bahwa protokol tersebut akan menjadi panduan agar masyarakat bisa tenang dan mendapat informasi yang jelas terkait virus corona (Dimas, 2020).

Berdasarkan hal tersebut, maka standar protokol juga akan diterapkan dalam seluruh aspek termasuk dalam pelaksanaan proyek konstruksi yang melibatkan banyak orang, sehingga di pelaksanaan protokol penting untuk dilaksanakan didalam proyek. Namun dibalik keharusan pelaksanaan protokol tersebut, para pihak juga perlu memikirkan dan menyiapkan SDM dalam hal ini Kesehatan Keselamatan Kerja (K3) untuk dapat menjalankan dan memastikan protokol terebut berjalan dengan baik. Maka dari itu dikeluarkannya Instruksi Menteri (INMEN) PUPR No 2 tahun 2020 tentang Pelaksanaan Protokol Pencegahan Covid-19 pada Proyek Konstruksi sebagai pedoman yang harus dilaksanakan oleh penyedia jasa dalam masa pelaksanaan konstruksi di lingkungan proyek.

Protokol atau Standard Operating Procedur (SOP) tersebut berlaku sepanjang belum demukannya vaksin Covid-19, maka obat paling tepat ialah mengubah kebiasaan bekerja mengikuti SOP yang berlaku di instansi (Sarah, 2020). Berdasarkan hal tersebut maka dari itu, pemberlakuan protokol Covid-19 juga merupakan hal mutlak dan berkelanjutan yang harus dilaksanakan dalam proyek konstruksi.

Maka dari itu, Kesiapan dari penyedia jasa dalam pelaksanan K3 untuk penerapkan protokol Covid-19 perlu diulas lebih jauh. Baik dari sisi kemampuan Sumber Daya Manusia (SDM), kesiapan perusahaan penyedia jasa dalam mengadakan peralatan pendukung pelaksanaan SOP protokol Covid-19 dilapangan, dan Menganalisis kesiapan penerapan protokol Covid19 pada proyek konstruksi.

\subsection{Aspek Kesehatan dalam K3 Konstruksi}

Penyakit akibat kerja adalah penyakit yang disebabkan oleh pekerjaan, alat kerja, bahan, proses maupun lingkungan kerja. Dengan demikian, penyakit akibat kerja merupakan penyakit yang artifisual atau man made disease (Adzim, 2013).

Dalam UU No 2 tahun 2017 disebutkan dalam pasal 47 yaitu pelindungan pekerja, memuat ketentuan tentang kewajiban para pihak dalam pelaksanaan keselamatan dan kesehatan kerja serta jaminan sosial; pelindungan terhadap pihak ketiga selain para pihak dan pekerja, memuat kewajiban para pihak dalam hal terjadi suatu peristiwa yang menimbulkan kerugian atau menyebabkan kecelakaan dan/atau kematian (UU No 2 Tahun 2017, 2017).

Selaras dengan hal tersebut menteri PU pun mengeluarkan Permen PUPR RI 21/PRT/M/2019, Keselamatan dan Kesehatan Kerja (K3) adalah segala kegiatan untuk menjamin dan melindungi keselamatan dan kesehatan tenaga kerja melalui upaya 
pencegahan kecelakaan kerja dan penyakit akibat kerja pada pekerjaan konstruksi (Menteri PUPR Republik Indonesia, 2019).

Berdasarkan hal diatas bisa disimpulkan bahwa K3 tidak hanya berpusat pada pencegahan kecelakaan kerja pada area konstruksi, tetapi juga pencegahan - pencegahan terhadap penyakit akibat kerja.

\subsection{Pandemi Corona Virus Disease 2019 (Covid - 19)}

Penyebaran Covid-19 di Indonesia semakin meluas disertai juga dengan penambahan jumlah kasus Covid-19 sehingga pemerintah mengeluarkan Keputusan Presiden No 11 Tahun 2020 tentang Kedaruratan Kesehatan Masyarakat Corona Virus Disease 2019 (Covid-19) sebagai penanggulangan dari pandemi ini (KEPPRES No 11 Tahun 2020, 2020).

Berbagai negara di dunia mulai menetapkan new normal. New normal yang dimaksud yaitu kebiasaan dan perilaku yang baru berbasis pada adaptasi untuk membudayakan perilaku hidup bersih dan sehat (KEMENKES RI, 2020). Hal ini berarti masyarakat dituntut untuk dapat melaksanaan pencegahan dan tetap waspada pada penyebaran virus tersebut sambil tetap melakukan kehidupan sosial seperti biasanya. Maka dari itu, baik WHO ataupun pemerintah Indonesia menetapkan protokol standar pencegahan Covid-19 sebagai langkah menuju new normal.

Mengacu pada keadaan new normal dengan menerapkan protokol pencegahan penyebaran Covid-19 tentu juga akan berdampak termasuk dalam pelaksanaan pekerjan konstruksi. Pelaksana konstruksi diminta untuk melaksanakan, dan mematuhi aturan protokol tersebut sebagai salah satu bagian dari SMK3 yang akan berlaku mulai sekarang dan akan datang. Hal itu diperkuat dengan dikeluarkannya standar protokol pencegahan penyebaran Covid19 pada proyek konstruksi oleh Menteri Pekerjaan Umum dan Perumahan Rakyat yang mengtur bagaimana pelaksanaan proyek konstruksi di masa pandemi Covid-19 diselenggarakan (Menteri Pekerjaan Umum Dan Perumahan Rakyat Republik Indonesia, 2018).

\subsection{Penerapan K3 dalam Proyek Konstruksi}

Penerapan k3 pada proyek merupakan pekerjaan yang melibatkan banyak unsur. Bukan saja manusia sebagai SDM atau pekerja, melainkan juga unsur-unsur pendukung lain. Dari mulai penggunaan alat-alat berat hingga pengadaan bahan material dalam jumlah besar. Maka dari itu, dunia konstruksi memiliki risiko kecelakaan kerja yang lebih tinggi dibandingkan jenis pekerjaan lainnya. Untuk itulah mengapa semua pihak yang terlibat didalam proyek konstruksi harus dapat memahami pentingnya penerapan K3 pada proyek konstruksi.

Pada dasarnya penerapan K3 dalam dunia profesionalisme kerja, mengacu pada risiko bahaya yang terjadi selama pekerjaan dilakukan. Tujuan dari penerapan K3 sendiri yaitu untuk mewujudkan keselamatan dan kesehatan kerja, terutama manusia atau tenaga kerja yang terlibat (Hutagaol, 2018).

Penerapan K3 dalam proyek konstruksi, disetiap negara memiliki kebijakan yang berbedabeda. Hanya saja, terdapat standar baku K3 internasional yaitu OHSAS 18001 yang merupakan standard internasional untuk menerapkan Sistem Manajemen Keselamatan dan Kesehatan Kerja di tempat kerja/ perusahaan, beserta pembaharuannya ISO 45001 yaitu merupakan Standar Internasional yang menetapkan persyaratan untuk sistem manajemen kesehatan dan keselamatan kerja (SMK3), dan standar ILO-OSH 2001 yang merupakan 
yang mengatur penerapan Sistem Manajemen dan Keselamatan dan Kesehatan Kerja secara Nasional maupun di tingkat Organisasi (Perusahaan). Dari keseluruhan standar tersebut pada akhirnya menjadi pedoman yang mengharuskan setiap negara melaksanakan dan mempunyai penerapan K3 minimal (Hutagaol, 2018). Untuk mewujudkan penerapakan K3 yang lebih optimal dalam dunia konstruksi, setiap perusahaan wajib memiliki Sistem Manajemen K3 (SMK3) yang akan mengatur penerapan K3 dengan baik.

Pemerintah juga mengeluarkan regulasi dan prosedur - prosedur pelaksanaan K3 yang selanjutnya di terjemahkan kedalam Sistem Manajemen K3 (SMK3) oleh perusahaan yang kemudian menjadi standar prosedur K3 yang akan dilaksanakan didalam lingkungan proyek perusahan yang bersangkutan.

\subsection{Protokol K3 Tambahan Terkait Pencegahan Covid-19 Pada Proyek Konstruksi}

Sesuai dengan dikeluarkanya INMEN No 2 tahun 2020 tentang standar protokol pencegahan penyebaran Covid-19 pada proyek konstruksi oleh Menteri Pekerjaan Umum dan Perumahan Rakyat maka untuk seluruh proyek konstruksi yang masih berjalan ataupun akan berjalan harus ikut mematuhi dan menjalankan dilingkungan kerja proyek masing masing. Adapun Instruksi Menteri tersebut memuat mekanisme tentang protokol pencegahan Covid-19 dalam penyelenggaraan jasa konstruksi yaitu : (Menteri PUPR Republik Indonesia, 2020)

- Membentuk satuan tugas (satgas) pencegahan Covid-19 yang dilakukan oleh pengguna jasa dan penyedia jasa;

- Menyediakan fasilitas pencegahan Covid-19 yang dilakukan oleh penyedia jasa pekerjaan konstruksi;

- Mengedukasi semua orang untuk menjaga diri dari Covid-19 oleh satuan tugas;

- Mengukur suhu semua orang pada setiap pagi, siang, dan sore yang dilakukan oleh penyedia jasa konstruksi.

- Membuat kerja sama penanganan suspect Covid-19 dengan Rumah Sakit dan Puskesmas setempat yang dilakukan penyedia jasa pekerjaan konstruksi;

- Menghentikan sementara pekerjaan jika terindikasi ada tenaga kerja yang terpapar Covid-19 yang dilakukan oleh pengguna dan atau penyedi jasa pekerjaan;

- Melakukan tindakan isolasi dan penyemprotan disinfektan sarana dan prasarana kantor dan lapangan yang dilakukan penyedia jasa dan pekerjaan konstruksi.

Berdasarkan instruksi diatas terlihat jelas bahwa penyedia jasa perlu memperbaharui SMK3 pada pelaksanaan poyek konstruksi agar dapat memenuhi hal - hal yang disyaratkan didalam instruksi tersebut dan pelaksanaan konstruksi dapat kembali dilanjutkan.

\subsection{Faktor Kesiapan Pelaksanaan Protokol Pencegahan Covid - 19 Pada Proyek Konstruksi}

Berdasarkan instruksi Menteri PUPR diatas, secara umum faktor kesiapan pelaksanan protokol pencegahan Covid-19 dapat dibagi menjadi 2 faktor yaitu : (Menteri PUPR Republik Indonesia, 2020)

1. Faktor kesiapan penyedia jasa dalam memfasilitasi sarana dan prasarana penegahan Covid-19 pada lingkungan proyek konstruksi yang meliputi : pengadaan ruang klinik di lapangan lengkap, pengukur suhu badan (thermoscan), pengukur tekanan darah, obat-obatan, dan petugas medis; memiliki kerjasama operasional perlindungan 
kesehatan dan pencegahan Covid-19 dengan rumah sakit dan/ atau pusat kesehatan masyarakat terdekat dengan lapangan proyek untuk tindakan darurat (emergency); menyediakan fasilitas pengukur suhu badan (thermoscan), penuci tangan dengan sabun disinvektan (hand sanitizer), tissue, masker di kantor dan lapangan proyek bagi para manager, insinyur, arsitek, karyawan/ staf, mandor, pekeria dan tamu proyek.

2. Faktor kesiapan SDM pada proyek konstruksi dalam menerapkan protokol pencegahan Covid-19 yaitu meliputi : membentuk Satuan Tugas Pencegahan Covid19; sosialisasi, edukasi, promosi teknik dan metoda pencegahaan Covid-19 serta perneriksaan (examination) potensi terinfeksi kepada semua orang, baik para manager, insinyur, arsitek, karyawan / staf, mandor, pekeda dan tamu proyek; memasang poster (flyers) baik digital maupun fisik tentang himbauan/ anjuran penegahan Covid-19, seperti mencuci tangan, memakai masker, untuk disebarluaskan atau dipasang di tempat-tempat strategis di lapangan proyek; menyampaikan penjelasan, anjuran, kampanye, promosi teknik pencegahan Covid19 dalam setiap kegiatan penyuluhan K3 pagi hari (safety morning talk); sosialisasi dan edukasi tahap - tahapan evakuasi apabila pekeria di lapangan proyek terpapr virus Covid-19; dan penyemprotan disinfektan pada tempat, fasilitas, pegangan dan peralatan kerja.

\section{METODOLOGI PENELITIAN}

\subsection{Metoda Dasar}

Penelitian merupakan penelitian deskriptif dengan pendekatan kualitatif yaitu dengan melakukan wawancara, observasi lapangan dan dokumentasi sebagai metoda pengumpulan data. Wawancara dilakukan kepada Project Manager dari masing - masing penyedia jasa yang kemudian digunakan untuk mengetahui pelaksanaan protokol K3 Covid-19 yang dilaksanakan pada proyek konstruksi berdasarkan INMEN No 2 Tahun 2020.

Sedangkan observasi dan dokumentasi digunakan sebagai perbandingan dan validasi hasil wawancara yang dilakukan sebelumnya. Observasi dilakukan dengan mengunjungi langsung proyek yang diteliti. Pada penelitian ini proyek yang diobservasi berjumlah 5 proyek yang berlokasi di Sumatera Barat. Proyek tersebut merupakan proyek bidang Sumber Daya Air (SDA) dengan rincian 2 proyek berada dibawah Balai Sungai Wilayah V (BWS V), dan 3 proyek dibawah Pengelolaan Sumber Daya Air Provinsi Sumatera Barat (PSDA Sumbar). Wawancara dilakukan pada bulan Juli - Agustus 2020. Hasil yang diperoleh kemudian diubah dalam bentuk persentase (kuantitatif) sehingga didapatkan tingkat kesiapan masing - masing penyedia jasa dalam pelaksanaan Protokol Pencegahan Covid-19 berdasarkan checklist dari INMEN No 2 tahun 2020 tersebut (Dafriansyah, 2014).

Poin atau nilai pembobotan pada masing - masing sub variabel diasumsikan adalah sama, yang berarti setiap komponen sub variabel memiliki pengaruh yang sama terhadap kesiapan penyedia jasa dalam pelaksanaan K3 protokol Covid-19. Jumlah bobot dibagi berdasarkan faktor yaitu faktor SDM dan Faktor Fasilitas dengan masing - masing faktor memiliki bobot total $100 \%$. Yang kemudian besaran bobot tersebut dibagi merata pada setiap variabel per faktornya. Sedangkan untuk penentuan tingkat kesiapan merujuk pada penelitian sebelumnya yaitu penelitian Dafriansyah (Dafriansyah, 2014) dan penelitian Arifin (Arifin, 2014). 


\subsection{Kriteria Penilaian}

Pada pengukuran tingkat penerapan pelaksanaan K3 pada proyek konstruksi dengan menggunakan pembobotan skala sebagai berikut yaitu :(Sugihardjo, 2018)

1. Untuk tingkat pencapaian 0-20\% termasuk tingkat penilaian Sangat Kurang.

2. Untuk tingkat pencapaian $21-40 \%$ termasuk tingkat penilaian Kurang.

3. Untuk tingkat pencapaian $41-60 \%$ termasuk tingkat penilaian Cukup.

4. Untuk tingkat pencapaian $61-80 \%$ termasuk tingkat penilaian Baik.

5. Untuk tingkat pencapaian $81-100 \%$ termasuk tingkat penilaian Sangat Baik.

\subsection{Variabel Penelitian}

Pengamantan terhadap kesiapan terbagi atas 2 faktor yaitu kesiapan SDM penyedia jasa dalam melaksanakan Protocol Pencegahan Covid-19 dan kesiapan perusahaan penyedia jasa dalam pengadaan peralatan pendukung SOP Protokol Covid-19, kemudian faktor tersebut dijabarkan menjadi 5 komponen besar (variabel) dan 14 Sub variabel.

Asumsi pembobotan pada masing - masing sub variabel adalah sama pada satu faktor yang sama, yang berarti masing - masing sub variabel dalam satu faktor memiliki pengaruh yang sama terhadap kesiapan penyedia jasa dalam pelaksanaan K3 protokol Covid-19. Sehingga kemudian digunakan sebagai dasar penelitian kesiapan pelaksanaan K3 protokol Covid-19 seperti Tabel 1 dibawah ini :

Tabel 1. Komponen penilaian kesiapan pelaksanaan k3 protokol covid - 19

\begin{tabular}{|c|c|c|c|c|}
\hline No & Faktor & Variabel & Sub Variabel & Bobot \\
\hline 1 & $\begin{array}{l}\text { Kesiapan } \\
\text { SDM }\end{array}$ & $\begin{array}{l}\text { Pengetahuan penyedia jasa } \\
\text { tentang Instruksi Menteri PUPR } \\
\text { No } 2 \text { tahun } 2020 \text { tentang } \\
\text { protokol pencegahan Covid-19 } \\
\text { pada area proyek konstruksi }\end{array}$ & $\mathrm{X} 1$ & $11.11 \%$ \\
\hline 2 & $\begin{array}{l}\text { Kesiapan } \\
\text { SDM }\end{array}$ & $\begin{array}{l}\text { Pembentukan Satgas (Satuan } \\
\text { Tugas) Pencegahan Covid-19 }\end{array}$ & $\begin{array}{l}\text { X2 Pembentukan Satgas (Satuan Tugas) } \\
\text { di lingkungan proyek } \\
\text { X3 Satgas terdiri Seluruh komponen } \\
\text { proyek } \\
\text { X4 Sosialisasi, edukasi, demo teknik dan } \\
\text { metoda tentang pencegahan dan } \\
\text { protokol Covid-19 } \\
\text { X5 Pemeriksaan potensi di area proyek }\end{array}$ & $\begin{array}{l}11.11 \% \\
11.11 \% \\
11.11 \%\end{array}$ \\
\hline 3 & $\begin{array}{l}\text { Kesiapan } \\
\text { Fasilitas }\end{array}$ & $\begin{array}{l}\text { Penyediaan Fasilitas Kesehatan } \\
\text { dilapangan }\end{array}$ & $\begin{array}{l}\text { X6 Penyediaan ruang klinik dilapangan } \\
\text { X7 Penyediaan Fasilitas klinik lengkap } \\
\text { X8 Kerja sama operasional } \\
\text { perlindungan kesehatan dengan Rumah } \\
\text { Sakit terdekat } \\
\text { X9 Penyediaan tempat pencuci tangan, } \\
\text { desinfektan, tissue, dan masker untuk } \\
\text { semua personil di area proyek }\end{array}$ & $\begin{array}{l}20 \% \\
20 \% \\
20 \% \\
20 \%\end{array}$ \\
\hline 4 & $\begin{array}{l}\text { Kesiapan } \\
\text { SDM }\end{array}$ & $\begin{array}{l}\text { Pelaksanaan Pencegahan Covid- } \\
19 \text { di Lapangan }\end{array}$ & $\begin{array}{l}\text { X10 Pememasang poster digital/ fisik } \\
\text { tentang anjuran pencegahan Covid-19 } \\
\text { X11 Penyampaian anjuran, dan } \\
\text { penyuluhan pencegahan Covid-19 pada } \\
\text { setiap kegiatan penyuluhan K3 pagi hari } \\
\text { X12 Larangan kepada orang yang } \\
\text { terindikasi suhu } \geq 38^{\circ} \mathrm{C} \text { untuk datang } \\
\text { kelokasi proyek }\end{array}$ & $\begin{array}{l}11.11 \% \\
11.11\end{array}$ \\
\hline
\end{tabular}




\begin{tabular}{lllll}
\hline No & Faktor & Variabel & Sub Variabel & Bobot \\
\hline & & & $\begin{array}{l}\text { X13 Pengukuran suhu tubuh kepada } \\
\text { seluruh pekerja, karyawan, setiap pagi, } \\
\text { siang, dan sore hari }\end{array}$ \\
\hline 5 & $\begin{array}{l}\text { Kesiapan } \\
\text { Fasilitas }\end{array}$ & $\begin{array}{l}\text { Pembiayaan Tambahan atas K3 } \\
\text { Protokol Covid-19 }\end{array}$ & X14 & $20 \%$ \\
\hline
\end{tabular}

\section{HASIL DAN PEMBAHASAN}

\subsection{Matrik Variabel dan Responden Terhadap Kesiapan Penyedia Jasa dalam Pelaksanaan Protokol K3 Covid-19 pada Proyek Konstruksi}

Pada Tabel 2 menunjukkan tingkat pelaksaan SOP protokol Covid-19 sesuai dengan Instruksi INMEN No. 2 tahun 2020 tentang Pelaksanaan K3 Protokol Covid-19 pada Proyek Konstruksi oleh penyedia jasa konstruksi. Terdapat 2 faktor utama yaitu kesiapan SDM dan kesiapan fasilitas yang disediakan oleh penyedia jasa di lingkungan proyek. Selanjutnya masing - masing faktor dijabarkan lebih rinci dalam 16 sub variabel yang mana masing masing sub variabel memiliki bobot yang akan menunjukkan tingkat kesiapan pelaksaan SOP tersebut. Masing - masing perusahaan akan diberikan tanda check (V) untuk setiap kegiatan yang dilaksanakan, dan tanda silang (X) untuk kegiatan yang tidak dilaksanakan.

Tabel 2. Matrik variabel dan responden terhadap kesiapan penyedia jasa dalam pelaksanaan protokol k3 covid-19 pada proyek konstruksi

\begin{tabular}{|c|c|c|c|c|c|c|c|c|c|c|}
\hline \multirow{4}{*}{ No } & \multirow{4}{*}{ Faktor } & \multirow{4}{*}{ Variabel } & \multirow{4}{*}{$\begin{array}{l}\text { Sub } \\
\text { Var. }\end{array}$} & \multirow{4}{*}{ Bobot } & \multicolumn{5}{|c|}{ Pelaksanaan oleh } & \multirow[t]{4}{*}{ Ket. } \\
\hline & & & & & \multicolumn{5}{|c|}{ Penyedia Jasa } & \\
\hline & & & & & $\mathbf{P}$ & $\mathbf{P}$ & $\mathbf{P}$ & $\mathbf{P}$ & $\mathbf{P}$ & \\
\hline & & & & & 1 & 2 & 3 & 4 & 5 & \\
\hline 1 & Kesiap & Pengetahuan & $\mathrm{X} 1$ & $11.11 \%$ & $\mathrm{~V}$ & $\mathrm{~V}$ & $\mathrm{X}$ & $\mathrm{X}$ & $\mathrm{X}$ & \\
\hline & an & penyedia jasa & & & & & & & & \\
\hline & & tentang Instruksi & & & & & & & & \\
\hline & & Menteri PUPR & & & & & & & & \\
\hline & & No 2 tahun 2020 & & & & & & & & \\
\hline \multirow[t]{6}{*}{2} & \multirow{6}{*}{$\begin{array}{l}\text { Kesiap } \\
\text { an } \\
\text { SDM }\end{array}$} & \multirow{6}{*}{$\begin{array}{l}\text { Pembentukan } \\
\text { Satgas (Satuan } \\
\text { Tugas) } \\
\text { Pencegahan } \\
\text { Covid-19 }\end{array}$} & $\mathrm{X} 2$ & $11.11 \%$ & $\mathrm{~V}$ & $\mathrm{~V}$ & $\mathrm{X}$ & $\mathrm{X}$ & $\mathrm{X}$ & \\
\hline & & & & & & & & & & \\
\hline & & & & & & & & & & \\
\hline & & & $\mathrm{X} 3$ & $11.11 \%$ & $\mathrm{~V}$ & $\mathrm{~V}$ & $\mathrm{X}$ & $\mathrm{X}$ & $\mathrm{X}$ & \\
\hline & & & $\mathrm{X} 4$ & $11.11 \%$ & $\mathrm{~V}$ & $\mathrm{~V}$ & $\mathrm{~V}$ & $\mathrm{X}$ & $\mathrm{V}$ & \\
\hline & & & $\mathrm{X} 5$ & $11.11 \%$ & $\mathrm{~V}$ & $\mathrm{~V}$ & $\mathrm{~V}$ & $\mathrm{~V}$ & $\mathrm{~V}$ & \\
\hline \multirow[t]{4}{*}{3} & \multirow{4}{*}{$\begin{array}{l}\text { Kesiap } \\
\text { an } \\
\text { Fasilit } \\
\text { as }\end{array}$} & \multirow{4}{*}{$\begin{array}{l}\text { Penyediaan } \\
\text { Fasilitas } \\
\text { Kesehatan } \\
\text { dilapangan }\end{array}$} & $\mathrm{X} 6$ & $20 \%$ & $\mathrm{~V}$ & $\mathrm{~V}$ & $\mathrm{X}$ & $\mathrm{X}$ & $\mathrm{X}$ & \\
\hline & & & $\mathrm{X} 7$ & $20 \%$ & $\mathrm{~V}$ & $\mathrm{~V}$ & $\mathrm{~V}$ & $\mathrm{~V}$ & $\mathrm{~V}$ & \\
\hline & & & $\mathrm{X} 8$ & $20 \%$ & $\mathrm{~V}$ & $\mathrm{~V}$ & $\mathrm{X}$ & $\mathrm{X}$ & $\mathrm{X}$ & \\
\hline & & & $\mathrm{X} 9$ & $20 \%$ & $\mathrm{~V}$ & $\mathrm{~V}$ & $\mathrm{~V}$ & $\mathrm{~V}$ & $\mathrm{~V}$ & $\begin{array}{l}\text { Disediakan tetapi } \\
\text { tidak dapat } \\
\text { dilaksanakan } \\
\text { dengan efektif }\end{array}$ \\
\hline \multirow[t]{5}{*}{4} & \multirow{5}{*}{$\begin{array}{l}\text { Kesiap } \\
\text { an } \\
\text { SDM }\end{array}$} & \multirow{5}{*}{$\begin{array}{l}\text { Pelaksanaan } \\
\text { Pencegahan } \\
\text { Covid-19 di } \\
\text { Lapangan }\end{array}$} & $\mathrm{X} 10$ & $11.11 \%$ & $\mathrm{~V}$ & V & V & $\mathrm{V}$ & V & \\
\hline & & & $\mathrm{X} 11$ & $11.11 \%$ & $\mathrm{~V}$ & $\mathrm{~V}$ & $\mathrm{~V}$ & $\mathrm{~V}$ & $\mathrm{X}$ & \\
\hline & & & $\mathrm{X} 12$ & $11.11 \%$ & $\mathrm{~V}$ & $\mathrm{~V}$ & $\mathrm{X}$ & $\mathrm{X}$ & $\mathrm{X}$ & Tidak dilakukan \\
\hline & & & & & & & & & & $\begin{array}{l}\text { pelaragan, tetapi } \\
\text { pemeriksaan } \\
\text { diawal bekerja. }\end{array}$ \\
\hline & & & $\mathrm{X} 13$ & $11.11 \%$ & V & $\mathrm{V}$ & $\mathrm{V}$ & $\mathrm{V}$ & $\mathrm{V}$ & $\begin{array}{l}\text { Dilakukan hanya } \\
\text { pada awal } \\
\text { pekeria datang }\end{array}$ \\
\hline
\end{tabular}




\begin{tabular}{|c|c|c|c|c|c|c|c|c|c|c|}
\hline \multirow{4}{*}{ No } & \multirow{4}{*}{ Faktor } & \multirow{4}{*}{ Variabel } & \multirow{3}{*}{$\begin{array}{l}\text { Sub } \\
\text { Var. }\end{array}$} & \multirow{3}{*}{ Bobot } & \multicolumn{5}{|c|}{$\begin{array}{c}\text { Pelaksanaan oleh } \\
\text { Penyedia Jasa }\end{array}$} & \multirow[t]{3}{*}{ Ket. } \\
\hline & & & & & $\mathbf{P}$ & $\mathbf{P}$ & $\mathbf{P}$ & $\mathbf{P}$ & $\mathbf{P}$ & \\
\hline & & & & & 1 & 2 & 3 & 4 & 5 & \\
\hline & & & & & & & & & & $\begin{array}{l}\text { dan atau tiap } \\
\text { hari atau tiap } \\
\text { minggu. }\end{array}$ \\
\hline 5 & & $\begin{array}{l}\text { Pembiayaan } \\
\text { Tambahan atas } \\
\text { K3 Protokol } \\
\text { Covid-19 }\end{array}$ & X14 & $20 \%$ & $\mathrm{~V}$ & $\mathrm{X}$ & $\mathrm{X}$ & $\mathrm{X}$ & $\mathrm{X}$ & $\begin{array}{l}\text { Penambahan } \\
\text { biaya tergantung } \\
\text { pada laporan } \\
\text { pertanggung } \\
\text { jawaban atau } \\
\text { menggunakan } \\
\text { dana K3. }\end{array}$ \\
\hline
\end{tabular}

Keterangan Tabel :

V : Dilaksanakan dilapangan sesuai Instruksi INMEN No. 2 tahun 2020 tentang Pelaksanaan K3 Protokol Covid-19 pada Proyek Konstruksi

X : Tidak dilaksanakan dilapangan sesuai Instruksi INMEN No. 2 tahun 2020 tentang Pelaksanaan K3 Protokol Covid-19 pada Proyek Konstruksi

Selanjutnya, dikarenakan hal yang dijelaskan diatas sehingga juga mempengaruhi fasilitas yang disediakan oleh penyedia jasa. Fasilitas seperti klinik dan petugas kesehatan lengkap tidak disediakan dilapangan, tetapi hanya kotak P3K saja.

\subsection{Kesiapan Penyedia Jasa Konstruksi Dalam Pelaksanaan K3 Selama Pandemi Covid-19 Di Provinsi Sumatera Barat}

Berdasarkan hasil dari Tabel 2 maka akan terlihat kegiatan yang dilaksanakan dan tidak oleh masing - masing perusaahaan. Tiap kegiatan yang dilaksanakan oleh perusahaan, kemudian akan diberikan bobot sesuai varibelnya.

Kemudian bobot pada variabel yang dilaksanakan per masing - masing perusahaan di jumlahkan berdasarkan faktornya dan juga bobot totalnya, sehingga dapat terlihat tingkat kesiapan dari masing - masing perusahaan tersebut terhadap faktor dan juga kesiapan keseluruhan masing - masing perusahaan. Bobot tersebut kemudian juga dirata - ratakan untuk melihat kesiapan secara umum terhadap faktor dan kesiapan total secara umum terhadap pelaksanaan SOP K3 Covid-19. Berdasarkan bobot tersebut juga kemudian dinilai tingkat kesiapannya. Untuk lebih jelasnya kemudian dirangkum seperti didalam Tabel 3 berikut ini.

Tabel 3. Kesiapan Penyedia Jasa Konstruksi Dalam Pelaksanaan K3 Selama Pandemi Covid-19 Di Provinsi Sumatera Barat

\begin{tabular}{|c|c|c|c|c|c|c|c|c|c|}
\hline \multirow{2}{*}{ No } & \multirow{2}{*}{ Faktor } & \multirow{2}{*}{$\begin{array}{l}\text { Juml } \\
\text { Item }\end{array}$} & \multicolumn{5}{|c|}{ Perusahaan } & \multirow{2}{*}{$\begin{array}{l}\text { Rata - } \\
\text { rata }\end{array}$} & \multirow{2}{*}{ TK } \\
\hline & & & $\mathrm{P} 1$ & $\mathrm{P} 2$ & P3 & $\mathrm{P} 4$ & P5 & & \\
\hline \multirow[t]{2}{*}{1} & Kesiapan & 9 & 9 & 8 & 5 & 4 & 4 & & \\
\hline & $\mathrm{SDM}$ & $\%$ & $100 \%$ & $88.89 \%$ & $55.56 \%$ & $44.44 \%$ & $44.44 \%$ & $66.66 \%$ & Baik \\
\hline \multirow[t]{2}{*}{2} & Kesiapan & 5 & 5 & 4 & 2 & 2 & 2 & & \\
\hline & Fasilitas & $\%$ & $100 \%$ & $80 \%$ & $40 \%$ & $40 \%$ & $40 \%$ & $60 \%$ & Cukup \\
\hline \multicolumn{2}{|c|}{$\begin{array}{l}\text { Persentase } \\
\text { penerapan secara } \\
\text { keseluruhan }\end{array}$} & $\%$ & $100 \%$ & $84.45 \%$ & $47.78 \%$ & $42.44 \%$ & $42.44 \%$ & $63.42 \%$ & Baik \\
\hline
\end{tabular}

Berdasarkan Tabel 3 diatas terlihat presentase pelaksanaan SOP K3 Covid-19 pada masing - masing perusahaan. Poin tertinggi terdapat pada perusahaan P1 dimana perusahaan 
tersebut telah melaksanakan protokol Covid - 19 sesuai dengan INMEN No 2 Tahun 2020. Sedangkan untuk perusahaan lainnya tidak melaksanakan secara menyeluruh INMEN No 2 Tahun 2020 sehingga mengakibatkan kecilnya poin pada penilaian perusahaan tersebut. Poin terendah ada pada perusahaan P4 dan P5. Hal tersebut dikarenakan perusahaan P4 dan P5 tidak melaksanakan sebagian besar protokol berdasarkan INMEN No 2 Tahun 2020. Kedua perusahaan tersebut hanya memenuhi protokol berdasarkan INMEN No 2 Tahun 2020 masing - masing sebesar 42.44\%. Sehingga persentase keseluruhan dalam pelaksanaan SOP protokol Covid -19 adalah 66.66\% untuk kesiapan SDM dan 60\% untuk kesiapan fasilitas, sehingga untuk persentase kesiapan secara keseluruhan adalah $63.42 \%$ atau dengan tingkat kesiapan "BAIK".

\section{KESIMPULAN DAN SARAN}

Hasil penelitian ini adalah kesiapan SDM dan personil K3 dilapangan dalam pelaksanaan protokol Covid-19 pada penelitian ini hanya $66.66 \%$ yang berarti kesiapan pelaksanaan protokol Covid-19 adalah "Baik". Kesiapan perusahaan penyedia jasa dalam mengadakan peralatan pendukung pelaksanaan SOP protokol Covid-19 dilapangan pada penelitian ini adalah $60 \%$ yang berarti kesiapan perusahaan mengadakan peralatan pendukung pelaksanaan SOP protokol Covid-19 adalah "Cukup". Sedangkan untuk penilaian kesiapan pelaksanaan protokol Covid-19 secara keseluruhan adalah $63.42 \%$. Nilai tersebut menunjukkan bahwa penyedia jasa belum sepenuhnya melaksankan INMEN No 2 Tahun 2020 dilapangan, terutama untuk item pembentukan satgas, penyediaan klinik, kerja sama dengan pusat kesehatan. Selain itu, kurangnya pengetahuan penyedia jasa mengenai isi dari INMEN No 2 Tahun 2020 juga menyebabkan banyaknya item protokol yang tidak dilaksanakan.

Dengan hasil penelitian diatas dapat digunakan sebagai pembuatan standar atau panduan yang lebih jelas terhadap implementasi dari INMEN sehingga terjadi persamaan presepsi penyedia jasa tenatang apa yang harus dilakukan dan dilengkapi untuk penyelenggaraan protokol Covid-19 di lingkungan proyek. Melakukan sosialisasi lagi kepada penyedia jasa konstruksi tentang penyelenggaraan protokol Covid-19. Dan Memasukkan pembiayaan protokol K3 Covid-19 ini kedalam kontrak pekerjaan sehingga penyedia jasa bisa menentukan budget yang tepat dalam pengadaan peralatan tambahan tersebut.

\section{UCAPAN TERIMAKASIH}

Makalah ini merupakan bagian dari luaran penelitian Riset Dasar tahun 2020 berjudul 'Pengaruh Pandemi Covid-19 Terhadap Kinerja Dan Sistem K3 Kontraktor Proyek Konstruksi Di Sumatera Barat'. Terimakasih kepada Lembaga Penelitian dan Pengabdian Masyarakat (LPPM) Universitas Andalas yang telah mendanai penelitian tersebut dengan nomor kontrak T/36/UN.16.17/PT.01.03-IS-RD/2020.

\section{DAFTAR PUSTAKA}

Adzim, H. I. (2013). Pengertian dan Elemen Sistem Manajemen K3 (Keselamatan dan Kesehatan Kerja).

Arifin, A. S. R. (2014). Pengukuran Tingkat Penerapan Norma, Standar, Prosedur Dan Kriteria Keselamatan Dan Kesehatan Kerja (NSPK K3) Pada Proyek Konstruksi. Jurnal Rekayasa Sipil, 10(2), 31-40.

Dafriansyah, P. (2014). Evaluasi Keandalan Sarana Penyelamatan Jiwa terhadap Bahaya Kebakaran pada Bangunan Gedung. Andalas Civil Engineering National Conference 2014, 1.

Dimas, C. (2020). Kantor Staf Presiden: Protokol Corona Merujuk ke Standar WHO.

Elvina, L. (2020). WHO Tetapkan Wabah Virus Corona Sebagai Pandemi Global. 
Hutagaol, A. (2018, September). Pentingnya K3 diterapkan di Proyek Konstruksi.

KEMENKES RI. (2020). Vaksin Covid-19 Belum Ditemukan, Pemerintah Siapkan Skenario New Normal. Kemenkes.Go.Id.

KEPPRES No 11 Tahun 2020. (2020). Keputusan Presiden No 11 Tahun 2020 tentang Kedaruratan Kesehatan Masyarakat Corona Virus Dieses 2019.

Menteri Pekerjaan Umum Dan Perumahan Rakyat Republik Indonesia. (2018). Peraturan Menteri Pekerjaan Umum Dan Perumahan Rakyat Republik Indonesia Nomor 02/Prt/M/2018 Tentang Perubahan Atas Peraturan Menteri Pekerjaan Umum Nomor 05/Prt/M/2014 Tentang Pedoman Sistem Manajemen Keselamatan Dan Kesehatan Kerja (Smk3) Konstruksi Bid.

Menteri PUPR Republik Indonesia. (2019). Peraturan Menteri nomor 21/PRT/M/2019 tentang Pedoman Sistem Manajemen Keselamatan Konstruksi.

Menteri PUPR Republik Indonesia. (2020). Instruksi Menteri Pekerjaan Umum dan Perumahn Rakyat No. 02/IN/M/2020 Tentang Protokol Pencegahan Penyebaran Corona Virus Dieses 2019 (Covid-19) dalam Penyelenggaraan Jasa Konstruksi.

Sarah. (2020). Pentingnya SOP Kesehatan di Masa New Normal.

UU No 2 Tahun 2017. (2017). Undang-Undang Republik Indonesia Nomor 2 Tahun 2017 Tentang Jasa Konstruksi.

Widyaningrum, G. L. (2020). WHO Tetapkan COVID-19 Sebagai Pandemi Global, Apa Maksudnya? 